\title{
HUBUNGAN STRES KERJA DENGAN PRODUKTIVITAS PEGAWAI PABRIK
}

\author{
Fatimatuz Zuhroh $^{1}$, Khusnul Aini ${ }^{1}$, Dwi Nur Aini ${ }^{1}$ \\ Program Studi Ners, STIKes Widya Husada Semarang \\ 1khusnul.aini@gmail.com
}

\begin{abstract}
ABSTRAK
Hasil studi pendahuluan di pabrik "X" kecamatan Mranggen kabupaten demak didapatkan informasi bahwa berbagai tekanan dari pekerjaan dapat menyebabkan mereka mengalami stres bekerja sehingga dapat memicu terjadinya penurunan produktivitas kerja. Tujuan dari penelitian ini adalah untuk mengetahui hubungan antara stres kerja dengan produktivitas pegawai pabrik kecamatan Mranggen kabupaten Demak. Penelitian ini dilaksanakan dengan metode kualitatif menggunakan rancangan Deskriptif Korelasional. Sampel penelitian ini berjumlah 196 orang karyawan yang terdiri dari seluruh karyawan bagian produksi. Cara pengambilan sampelnya menggunakan teknik Purposive Sampling.Dan menggunakan analisis uji statistics Rank Spearman. Hasil penelitian menujukkan adanya hubungan antara stres kerja dengan Produktivitas kerja pada pegawai pabrik di kecamatan Mranggen kabupaten demak dengan hasil $p$ value 0,000 ( $p<0,05)$. Kesimpulan dari penelitian adalah ada hubungan yang sangat signifikan antara stres kerja dengan produktivitas pegawai pabrik di kecamatan Mranggen kabupaten Demak. Sehingga perlu pencegahan dan penanganan masalah stres pada karyawan untuk meningkatkan produktivitas kerjanya.
\end{abstract}

Kata kunci: stres kerja, produktivitas

\section{THE RELATIONSHIP BETWEEN WORK STRES AND WORK PERFORMANCE OF EMPLOYEES}

\begin{abstract}
The early study results of the " $X$ " factory got information that the various pressure from work as exhaustion, salary that did not justify the high demand of life, workload higher when work never done, think bored towards their job monotonous and everything anything to do with the work may be causing they had stres worked so as can trigger a decline in labor productivity. The purpose of the study to know relationship between work stres and work performance of employees in Mranggen Demak. This study was conducted quantitative design descriptive correlation. Sample were 196 workers in consisting of all employees of production department. The selection sample used purposive sampling. And statistical test Rank Spearman. The result showed relationship between work stres and work performance of employees At Factory in Mranggen Demak with p value 0,000 ( $p<0,05)$.

There was a highly significant relationship between work stres and work performance of employees At Factory Mranggen Demak. So we needed prevention and problem handling stres on employees to increase productivity of work.
\end{abstract}

Keywords : work stres, employees performance

\section{PENDAHULUAN}

Ketika orang dewasa sudah memasuki dunia kerja, biasanya orang dewasa cenderung merasa tertekan oleh tuntutan pekerjaan yang mereka jalani. Mereka biasanya kurang setia atau memiliki loyalitas terhadap perusahaan yang rendah dan cenderung mencari pekerjaan lain yang dianggap lebih memuaskan dan lebih dapat menjamin atas kelangsungan hidupnya. Salah satu tugas perkembangan seseorang yang telah memasuki masa dewasa awal adalah memasuki dunia kerja dan karier. Dalam proses perjalanan dalam fase ini, seseorang dituntut untuk dapat menentukan jenjang karier yang tepat bagi dirinya. Seorang individu dalam menjalani hidupnya ditengah fase ini diharapkan sudah memiliki pekerjaan (Anoraga, 2009).

Studi lain di Amerika menemukan 78\% dari responden menyatakan bahwa pekerjaan adalah sumber stres mereka yang utama dan hanya 35\% mengatakan bahwa mereka merasa senang dan puas terhadap pekerjaan mereka, 
dan setengah dari mereka merasa mengalami tekanan hidup yang semakin meningkat selama 10 tahun terakhir. Pengakuan terhadap adanya stres kerja tidak hanya merupakan sebuah fenomena di Amerika Serikat, WHO menganggapnya sebagai "penyakit abad dua puluhan" mengindikasikan bahwa stres kerja menjadi lebih banyak di hampir setiap pekerjaan diseluruh dunia dan telah menjadi epidemik global (Greenberg, 2002). Tuntutan akan kinerja karyawan yang tinggi memang sudah menjadi bagian dari semua perusahaan. Namun fakta yang ada sekarang memperlihatkan bahwa belum semua karyawan memiliki kinerja yang tinggi sesuai dengan harapan perusahaan. Masih banyak terdapat karyawan yang memiliki kinerja yang rendah. Berdasarkan peringkat indeks kinerja yang telah dilakukan World Investment Report (WIR) tahun 2003, indeks kinerja Indonesia menempati urutan ke 138 dari 140 negara. Peringkat ini dengan memperhatikan indikator tingkat kehadiran, kualitas pekerjaan (profesionalisme dalam bekerja), dan kuantitas pekerjaan karyawan Indonesia yang masih tergolong rendah (Yuli, 2004).

Penelitian tentang stres kerja dengan produktivitas kerja sudah pernah dilakukan oleh Saputri (2012), penelitian ini membahas mengenai hubungan stres kerja dengan produktivitas kerja pada karyawan $\mathrm{CV}$. Mediatama Surakarta. Kesimpulan dari penelitian ini menyatakan ada hubungan negatif yang sangatsignifikan antara stres kerja dengan produktivitas kerja, semakintinggi stres kerja maka semakin rendah produktivitas kerja, begitu sebaliknyasemakin rendah stres kerja maka semakin tinggi produktivitas kerja.
Dari hasil studi pendahuluan pada tanggal 24 Januari 2016 jam 18.30 yang telah dilakukan dengan 5 orang pekerja bagian produksi pupuk pabrik " $X$ " kecamatan Mranggen kabupaten Demak didapatkan informasi bahwa berbagai tekanan dari pekerjaan seperti kelelahan, gaji yang tidak sepadan dengan tingginya kebutuhan hidup, beban kerja yang semakin tinggi saat pekerjaan tak kunjung selesai, rasa bosan terhadap pekerjaan yang monoton dan segala sesuatu yang ada kaitannya dengan pekerjaan dapat menyebabkan mereka mengalami stres bekerja sehingga dapat memicu terjadinya penurunan produktivitas kerja, seperti gagalnya hasil produksi yang tidak sesuai harapan, keterlambatan, hilangnya gairah kerja, kejenuhan dalam bekerja serta angka kehadiran pekerja $<100 \%$. Berbagai alasan yang telah didapatkan dari hasil wawancara tersebut maka peneliti ingin mengembangkan penelitian dengan judul "Hubungan Antara Stres Bekerja dengan produktivitas karyawan di pabrik " $\mathrm{X}$ " Kecamatan Mranggen Kabupaten Demak.

\section{METODE}

Penelitian ini merupakan penelitian kuantitatif dengan pendekatan cross sectional. Variabel penelitian meliputi variabel Independen yaitu stres bekerja dan variabel dependen yaitu produktivitas kerja. populasi penelitian adalah karyawan bagian produksi dan jumlah sampel adalah 196 karyawan yang sesuai kriteria. Teknik sampling menggunakan purposive sampling. pengambilan data menggunakan kuesioner. Analisis data dilakukan menggunakan uji Rank Spearman.

\section{HASIL}

Hasil penelitian dapat dilihat pada tabel berikut.

Tabel 1.

Karakteristik responden berdasarkan umur

\begin{tabular}{lcc}
\hline \multicolumn{1}{c}{ Variabel } & $\mathrm{f}$ & $\%$ \\
\hline Usia & 27 & 13,8 \\
$<25$ th & 165 & 84,2 \\
$25-40$ th & 4 & 2,0 \\
$>40$ th & 23 & \\
\hline Status perkawinan & 173 & 11,7 \\
Belum Menikah & & 88,3 \\
Menikah & 5 & 2,6 \\
Lama kerja & 191 & 97,4 \\
$<1$ tahun & & \\
$>1$ tahun & & \\
\end{tabular}


Tabel 2.

Distribusi frekuensi stres bekerja

\begin{tabular}{lcc}
\hline Stres Bekerja & f & $\%$ \\
\hline Ringan & 93 & 47,4 \\
Sedang & 82 & 41,8 \\
Berat & 21 & 10,7
\end{tabular}

Tabel 3.

Distribusi frekuensi produktivitas kerja

\begin{tabular}{lcc}
\hline Produktivitas Kerja & f & $\%$ \\
\hline Rendah & 77 & 39,3 \\
Sedang & 51 & 26,0 \\
Tinggi & 68 & 34,7 \\
\hline
\end{tabular}

Tabel 4.

Pengaruh stres bekerja dengan produktivitas kerja

\begin{tabular}{|c|c|c|c|c|c|c|c|c|c|c|}
\hline \multirow{3}{*}{$\begin{array}{c}\text { Stres } \\
\text { bekerja }\end{array}$} & \multicolumn{6}{|c|}{ Produktivitas kerja } & \multicolumn{2}{|c|}{ Total } & \multirow[t]{3}{*}{$\mathrm{X}^{2}$} & \multirow[t]{2}{*}{$\mathrm{p}$ value } \\
\hline & \multicolumn{2}{|c|}{ Rendah } & \multicolumn{2}{|c|}{ Sedang } & \multicolumn{2}{|c|}{ Tinggi } & & & & \\
\hline & $f$ & $\%$ & $f$ & $\%$ & $f$ & $\%$ & $\mathrm{f}$ & $\%$ & & \\
\hline Ringan & 38 & 19,4 & 16 & 8,2 & 39 & 19,9 & 93 & 47,4 & & \\
\hline Sedang & 19 & 9,7 & 34 & 17,3 & 29 & 14,8 & 82 & 41,8 & -0.623 & 0,000 \\
\hline Berat & 11 & 5,6 & 1 & 0,5 & 9 & 4,6 & 21 & 10,7 & & \\
\hline Total & 68 & 34,7 & 51 & 26,0 & 77 & 39,3 & 196 & 100 & & \\
\hline
\end{tabular}

produktivitas kerja. Data yang diperoleh dari penelitian ini menggunakan analisis Rank Spearman. Dari uji ini diperoleh hasil bahwa nilai rho $-0,623$ dan $\mathrm{p}$ value $0,000(\mathrm{p}<0,05)$ yang dapat disimpulkan $\mathrm{H}_{\mathrm{a}}$ diterima dan $\mathrm{H}_{0}$ ditolak yang berarti ada hubungan antara stres bekerja dengan kinerja karyawan pabrik " $\mathrm{X}$ " kecamatan Mranggen kabupaten Demak.

\section{PEMBAHASAN}

1. Umur

Hasil penelitian ini didapatkan hasil bahwa menurut kelompok umur, responden dengan umur 25-40 tahun adalah yang paling banyak dengan jumlah 165 orang $(84,2 \%)$ sebagai usia produktif. Urutan kedua terbanyak adalah kelompok umur $<25$ tahun yaitu sebanyak 27 orang $(13,8 \%)$ dan yang terakhir umur $>40$ tahun sebanyak 4 orang $(2,0)$ saja yang merupakan karyawan senior. Bila diperhatikan, kecenderungan terjadinya produktivitas kerja menurun seiring dengan meningkatnya umur. Menurut Ravianto (2014), umumnya karyawan yang sudah berumur lanjut mempunyai tenaga fisik relatif terbatas daripada karyawan yang masih muda untuk itu lebih banyak menggunakan karyawan yang lebih muda karena fisiknya yang lebih kuat. Pernyataan ini sesuai dengan data hasil penelitian, dimana
2. Status perkawinan

Berdasarkan status perkawinan, sebagian responden sudah menikah sebanyak 173 responden $(88,3 \%)$ dan sisanya 23 responden $(11,7 \%)$ belum menikah. Menurut surveisurvei nasional secara konsisten menunjukkan bahwa orang sangat mementingkan hubungan keluarga dan pribadi. Berbagai kesulitan dalam hidup perkawinan, retaknya hubungan dan kesulitan masalah disiplin dengan anak-anak adalah beberapa contoh masalah hubungan yang menciptakan stres bagi karyawan. Hal ini sesuai dengan teori National Safety Council (2004) yang mana penyebab stres di kelompokkan dalam tiga kategori, yaitu penyebab organisasi, individu dan lingkungan. Pada kelompok individu disebutkan bahwa status perkawinan bisa menimbulkan stres bagi karyawan, seperti pertentangan antara karir dan tanggung jawab keluarga, dan perawatan anak yang tidak adekuat.

\section{Lama kerja}

Berdasarkan lama kerja, sebanyak 191 orang $(97,4 \%)$ bekerja $>1$ tahun dan sebanyak 5 orang $(2,6 \%)$ bekerja $<1$ tahun. Menurut Robbins (2008) di dalam organisasi terdapat beberapa faktor yang dapat menimbulkan stres kerja, yaitu tuntutan tugas, tuntutan peran dan 
tuntutan pribadi. Semakin lama seseorang bekerja pada suatu perusahaan maka semakin tinggi pula faktor yang dapat memicu stres. Hal ini diakibatkan oleh pekerjaan yang monoton, kondisi ekonomi yang tidak stabil serta tuntutan pekerjaan yang harus cepat terselesaikan sehingga dapat memicu ketegangan dalam bekerja atau stres kerja pada karyawannya.

\section{Stres bekerja}

Dari hasil penelitian diperoleh data bahwa stres bekerja pabrik " $X$ " kecamatan Mranggen kabupaten Demak lebih dominan mengalami stres ringan. Dimana saat dilakukan pengumpulan data hasil dari penelitian ini responden sering mengalami kelelahan, seperti tangan terasa capek, betis terasa pegal, dan nyeri punggung. Faktor ini disebabkan karena terlalu lama responden di forcer untuk bekerja tiap hari dengan waktu istirahat yang sangat sedikit. Begitu juga kadang mereka kurang berinteraksi dengan teman kerja sehingga terjadi kesenjangan antara pekerja dengan pekerja lain. Apalagi disaat hasil produksi yang tidak sesuai dengan kriteria uji lab, maka mereka harus daur ulang kembali sehingga membutuhkan waktu yang lebih lama untuk memproduksinya.

Menurut Anoraga (2009) apabila perubahan dalam lingkungannya sudah menjadi sedemikian cepat dan ganas, sehingga seseorang sudah merasa tidak sanggup untuk menghadapi atau menyesuaikan dirinya terhadap perubahan tersebut, maka ambang ketahanannya terhadap stres mulai terlampaui. Kondisi inilah yang harus dihindarkan atau ditanggulangi. Dari hasil penelitian ini perlu digaris bawahi bahwa sebanyak 5,6 \% responden mengalami stres berat. Maka dari itu perlu penanganan dan pencegahan khusus bagi karyawan tersebut untuk menurunkan stres bekerja mereka yang nantinya akan berdampak pada gangguan jiwa. Contohnya, perlu diadakan bimbingan konseling bagi tiaptiap karyawan tiap bulan di pabrik " $\mathrm{X}$ " kecamatan Mranggen kabupaten Demak.

\section{Produktivitas kerja}

Dari hasil penelitian ini didapatkan data bahwa produktivitas dari pabrik "X" kecamatan Mranggen kabupaten Demak masuk dalam kategori tinggi sebanyak 77 orang $(39,3 \%)$ dan produktivitas rendah sebanyak 68 orang $(34,7 \%)$. Hasil penelitian ini dapat dilihat dari jawaban responden bahwa mereka selalu datang tepat waktu dan pulang kerja tepat waktu, karena kunci dari produktivitas kerja adalah harus disiplin, memiliki semangat kerja tinggi serta dapat meningkatkan hasil produksi sesuai dengan indikator produktivitas kerja. Karena hasil produksi harus sesuai dengan kriteria uji lab, maka dalam menghasilkan produksi kadang tidak sesuai dengan target maka mereka harus bekerja lebih giat lagi untuk menghasilkan pupuk yang sesuai dengan standar pabrik. Sehingga nilai dari produktivitas kerja pekerja juga tergolong rendah. Penyebab lain dari produktivitas kerja rendah adalah program pelatihan dari pabrik sangatlah minim. Kadang dalam setahun belum tentu diadakan pelatihan, seperti K3, pengolahan limbah, dll. Dengan selisih jumlah yang sedikit dapat disimpulkan bahwa faktorfaktor lain dapat mempengaruhi produktivitas kerja seseorang berbeda yang satu dengan yang lainnya.

6. Hubungan antara stres bekerja dengan produktivitas kerja

Hasil penelitian ditemukan bahwa responden yang banyak mengalami stres bekerja adalah tenaga kerja dengan produktivitas tinggi 39 orang $(41,9 \%)$ dan yang paling sedikit mengalami stres kerja adalah tenaga kerja yang dengan tingkat produktivitas sedang yaitu sebesar 1 orang (4,8\%). Kondisi stres seseorang mempengaruhi produktivitas kerjanya. stres ringan masih adaptif terhadap kinerja seseorang sehingga tidak terlalu mengganggu. Dari hasil ini dapat disimpulkan bahwa stres ringan memberikan pengaruh terhadap produktivitas kerja yang tinggi. Hal ini sesuai dengan teori Ardana, dkk (2009) bahwa salah satu alasan mengapa stres perlu untuk dipahami adalah stres berhubungan erat dengan produktivitas. Karyawan yang mengalami stres kerja tidak dapat bekerja secara optimal sehingga akan memberi dampak yang negatif pada hasil kerjanya atau dengan kata lain karyawan tidak dapat mengoptimalkan hasil kerjanya.

Analisis bivariat yang telah dilakukan diperoleh hasil rho $=-0,623 ; \mathrm{p}$ value $=0,000$ $(\mathrm{p}<0,05)$ yang artinya ada hubungan yang bermakna antara stres bekerja dengan kinerja karyawan pabrik " $\mathrm{X}$ ". Hal ini sesuai dengan penelitian sebelumnya oleh Saputri (2012) yang menyatakan bahwa ada hubungan yang sangat signifikan antara stres kerja dengan produktivitas kerja pada karyawan $\mathrm{CV}$ Mediatama Surakarta. Dari hasil penelitian ini 
dapat dilihat bahwa jika karyawan mengalami stres kerja dalam pekerjaannya maka dapat menurunkan produktivitas kerja bagi perusahaan. Antara stres bekerja dengan produktivitas kerja, gejala yang lebih menonjol adalah gejala perilaku. Gejala tersebut dapat dilihat dari hasil kuesioner yang telah diisi oleh responden.

\section{SIMPULAN DAN SARAN \\ Simpulan}

1. Stres kerja para pekerja tergolong ringan dengan persentase $47,4 \%$. Sedangkan sebanyak 41,8\% mengalami stres sedang dan sisanya mengalami stres berat dengan persentase $10,7 \%$.

2. Produktivitas kerja Pabrik " $X$ " lebih dominan tinggi dengan persentase $39,3 \%$, sebanyak $34,7 \%$ memiliki produktivitas kerja rendah dan sebanyak $26,0 \%$ memiliki produktivitas kerja sedang.

3. Ada hubungan yang sangat signifikan antara stres bekerja dengan produktivitas kerja. Nilai korelasi (r) $-0,623$, p value $0,000(\mathrm{p}<0,05)$

\section{Saran}

1. Bagi karyawan, untuk mencegah terjadinya stres kerja maka perlu diimbangi dengan pola hidup yang sehat. Contohnya, olahraga teratur, makan-makanan bergizi, istirahat yang cukup serta luangkan waktu untuk refreshing ataupun pemberian reward untuk memacu pekerja untuk lebih giat lagi dalam bekerja.

2. Bagi pabrik " $X$ ", perlunya diadakan evaluasi kerja tiap 6 bulan sekali guna mencegah stres kerja berkelanjutan yang berdampak pada produktivitas kerja karyawan. Dan perlunya program pencegahan dan penanganan stres kerja yang dilakukan berkesinambungan.

\section{DAFTAR PUSTAKA}

Anoraga, Panji. 2009. Psikologi Kerja. Cetakan ke-5.Jakarta : Rineka Cipta

Arikunto, Prof. Dr. Suharsimi. 2013. Prosedur Penelitian : Suatu Pendekatan Praktik. Cetakan k-15.Jakarta : Rineka Cipta

Ardana, I Komang Dkk. 2012.Manajemen Sumber Daya Manusia. Yogyakarta : Graha Ilmu

Dantes, Prof. dr. Nyoman. 2012. Metode Penelitian. Yogyakarta : Andi
Faliza, Nur. 2011. Analisis Pengaruh Kepuasan dan Stres Kerja Terhadap Produktivitas Karyawan Pada PT. Mediatama Indokonsult Banda Aceh. Sekolah Pasca Sarjana. Sumatera Utara (diakses tanggal 14 Januari 2016)

Harrisma, Okta Wisudawati. 2013. Pengaruh Stres Kerja Terhadap Produktivitas Kerja Melalui Kepuasan Kerja. Sekolah Pasca Sarjana. Universitas Negeri Surabaya (diakses tanggal 24 Juni 2016)

Hasibuan, S.P. 2008. Manajemen Sumber Daya Manusia. Edisi Revisi. Jakarta : Bumi Aksara

Inayani, Yani. 2011. Analisis Perbedaan Faktor Demografi Dalam Strategi Penanggulangan Stres Kerja : Studi Kasus Dinas Kesehatan Kota Bogor. Tesis S-2. Sekolah Pasca Sarjana. Institut Pertanian Bogor (diakses tanggal 14 Januari 2016)

Luthans, J. Fred. 2006. Perilaku Organisasi. Terjemahan Oleh Vivin Andhika Yuwono, Dkk. Edisi Sepuluh .Yogyakarta : Andi

Mangkunegara, A.A. Anwar Prabu. 2008. Manajemen Sumber Daya Manusia Peusahaan. Cetakan ke-8.Bandung : Rosda

Notoatmojo, Prof. Dr. Soekidjo. 2012. Metodologi Penelitian Kesehatan. Edisi Revisi. Jakarta : Rineka Cipta

Nursalam. 2013. Konsep dan Penerapan Metodologi Penelitian Ilmu Keperawatan. Jakarta : Salemba Medika

Putri, Gadis W.Y. 2014. Hubungan Stres Kerja Dengan Tingkat Produktivitas Tenaga Kerja Di CV."X". Sekolah Pasca Sarjana. Universitas Airlangga (diakses tanggal 24 Juni 2016)

Riyanto, Agus. 2013. Statistik Deskriptif Untuk Kesehatan. Yogyakarta : Nuha Medika

Robbins, Stephen P. 2006. Perilaku Organisasi. Edisi Sepuluh. Terjemahan Oleh Benyamin Molan..Klaten : PT. Intan Sejati 
Robbins, Stephen P. dan Judge, Timothy A. 2008.Perilaku Organisasi. Jilid 1.Edisi 12. Terjemahan Oleh Diana Angelica..Jakarta : Salemba Empoa

Sinungan, M. 2009. Cetakan Ke8.Produktivitas : Apa Dan Bagaimana. Jakarta : Bumi Aksara

Wijono, S. 2010. Psikologi Industri Dan Organisasi : Dalam Suatu Bidang Gerak Psikologi Sumber Daya Manusia. Jakarta. Kencana

Windiyananti, Adila. 2010. Hubungan Antara Kelelahan Kerja Dengan Stres Kerja
Pada Tenaga Kerja Di Pengolahan Kayu Lapis Wreksa Rahayu Boyolali. Sekolah Pasca DIV. Universitas Sebelas Mare (diakses tanggal 24 Juni 2016)

Wexley \& Yuki.G.A. 2014.Perilaku Organisasi Dan Psikologi Personalia. Jakarta. Rineka Cipta

Yuliaseti. 2012. Konstribusi Stres Pada Produktivitas Kerja. Anima.No.4. volume 16. Indonesian Pshycological Journal. 